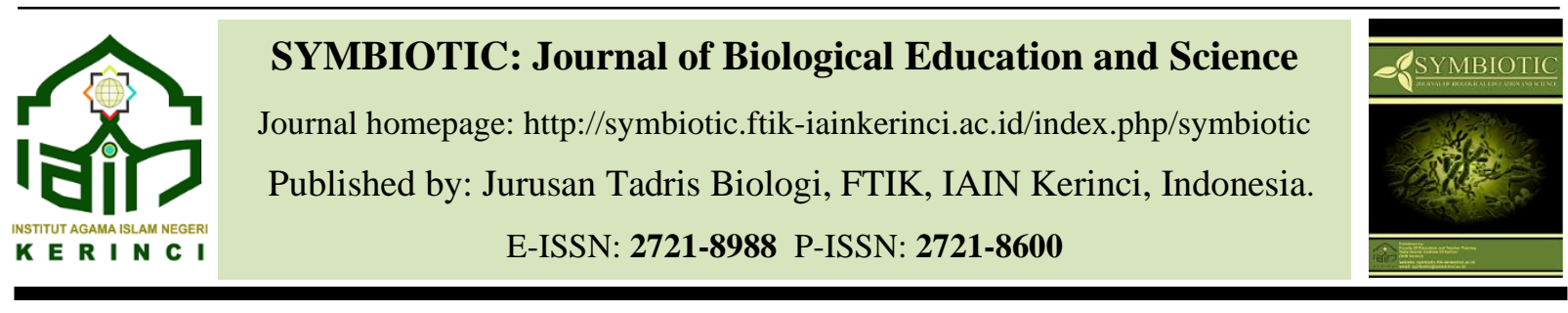

\title{
Pemanfaatan Tanaman Hias Sebagai Media Pembelajaran Biologi
}

\author{
Lia Angela ${ }^{1}$, Nisa Novita Putri², Toni Haryanto ${ }^{3}$, Husnin Nahry Yarza ${ }^{4}$ \\ ${ }^{1,2,3}$ Institut Agama Islam Negeri Kerinci, Sungai Penuh, Jambi \\ ${ }^{4}$ Universitas Muhammadiyah Prof. Dr. Hamka, Jakarta \\ e-mail korespondensi: liaangela@iainkerinci.ac.id
}

\begin{abstract}
The research aims to determine the types of ornamental plants found in the SMP Negeri 11 Sungai Penuh school environment. This research was conducted in two stages: the first stage was identifying ornamental plant species found in the school yard and made as learning media in the form of a photo album. The second stage applies the identification results in the form of photo album media in biology learning. The method used in this study, in the first stage uses descriptive analysis with survey methods and the second stage uses quantitative analysis. The instruments used in this study were questionnaires, key books of determination and photos of plants from internet references. The results of this study were found 19 types of ornamental plants found in the school yard of SMP Negeri 11 Sungai Penuh and the dominant ornamental plant is the type of Araceae. The results of student responses to the ornamental plant media obtained an average value of $89.3 \%$ with a very good category.
\end{abstract}

Keywords: Ornamental Plants, Learning Media, Biology Learning

\begin{abstract}
ABSTRAK
Penelitian ini bertujuan untuk mengetahui jenis-jenis tanaman hias yang terdapat di lingkungan sekolah SMP Negeri 11 Sungai Penuh. Penelitian ini dilaksanakan dengan dua tahapan yaitu tahap pertama megidentifikasi jenis tanaman hias yang terdapat di pekarangan sekolah dan dibuat sebagai media pembelajaran dalam bentuk album foto. Tahap kedua menerapkan hasil identifikasi berupa media album foto dalam pembelajaran biologi. Metode yang digunakan dalam peneltiian ini, pada tahap pertama menggunakan analisa deskriptif dengan metode survei dan tahap kedua menggunakan analisa kuantitatif. Instrumen yang digunakan dalam peneltian ini adalah angket, buku kunci determinasi dan foto tumbuhan dari referensi internet. Hasil penelitian ini adalah ditemukan 19 jenis tanaman hias yang terdapat di pekarangan sekolah SMP Negeri 11 Sungai Penuh dan tanaman hias yang dominan adalah jenis Araceae. Hasil respon siswa terhadap media tanaman hias diperoleh nilai rata-rata yaitu 89,3\% dengan kategori sangat baik.
\end{abstract}

Kata Kunci :Tanaman Hias, Media Pembelajaran,Pembelajaran Biologi

\section{PENDAHULUAN}

Lingkungan merupakan suatu sistem kesamaan ruang yang dapat mempengaruhi keberadan manusia, faktor abiotik dan biotik. Lingkungan yang ada di sekitar sekolah dan siswa adalah sumber belajar yang mampu memaksimalkan usaha pencapaian tujuan pembelajaran. Penggunaan dan pemanfaatan lingkungan sebai media pembelajaran akan dapat menambah referensi wawasan dan pengetahuan siswa. Siswa dapat belajar dengan tidak dibatasi oleh dinding kelas, selain itu siswa dapat mendapatkan pengalaman secara langsung dari pemanfaatan lingkungan khsususnya lingkungan 
sekolah. Lingkungan sekolah dapat memberi pengalaman secara langsung bagi siswa. Pemanfaatan lingkungan memiliki banyak manfaat yang bisa diambil, yaitu sebagai salah satu sumber belajar berbagai konsep ilmu pengetahuan.

Berdasarkan hasil observasi, lingkungan sekolah SMP Negeri 11 Sungai Penuh memiliki jenis tanaman hias yang beragam. Kelompok tanaman hias ini menduduki pekarangan sekolah. Tanaman hias yang ditemui di pekarangan sekolah SMP Negeri 11 Sungai Penuh ada yang sengaja dibudidayakan oleh majelis guru dan terdapat jenis tanaman yang tidak mendapat perawatan. Tumbuhan yang terdapat di pekarangan sekolah SMP Negeri 11 Sungai Penuh didominasi oleh jenis tanaman hias. Hal ini dikarenakan tanaman hias mempunyai nilai keindahan selain nilai keasrian. Informasi yang diperoleh bahwa tanaman hias yang terdapat di pekarangan sekolah belum diidentifikasi secara baik. Hal ini dikarenakan pihak sekolah belum mendapatkan informasi mengenai nama ilmiah dan deskripsi morfologi tumbuhan tersebut.

Menurut (Gembong: 1998) tujuan mengidentifikasi tumbuhan adalah untuk memudahkan dalam mengelompokkan jenis tumbuan berdasarkan ilmu taksonomi. Berdasarkan hal ini maka perlu dilakukan identifikasi jenis tanaman hias yang ada di pekarangan sekolah dan dengan tujuan hasil identifikasi yang diperoleh dapat dimanfaatkan sebagai media pembelajaran biologi.

Media merupakan alat bantu mengajar yang berkembang dengan pesat sesuai dengan kemajuan tenologi. Aneka jenis media digunakan dalam proses pemebelajaran untuk membantu pencapaian tujuan pembelajaran. Pemanafaaat media pembelajaran dalam proses pembelajaran disesuaikan dengan kondisi, waktu, dan materi yang akan disampaikan. Dalam proses pemebelajaran, media didefenisikan sebagai sesutau yang memberikan informasi dan pengetahuan dalam interaksi antara siswa dan guru maupun antara siswa dengan siswa. Hasil penelitian (Wulandari, Saptasari dan Mahana: 2016) menjelaskan bahwa pemanfaatan tumbuhan di taman hutan raya sebagai media penunjang identifikasi dapat membantu mahasiswa dalam mengidentifikasi jenis tumbuhan. Lingkungan merupakan sumber belajar yang dapat dimanfaatkan, karena melalui lingkungan dapat menciptakan pembelaajran yang konstektual.

Penggunaan bahan ajar berbasis constektual teaching and learning dapat meningkatkan daya tarik siswa dalam mengikuti pembelajaran. jenis-jenis tumbuhan yang terdapat di lingkungan sekolah perlu diidentifikasi dan dijadikan sebagai media pembelajaran untuk membantu siswa dalam memahami materi pelajaran dengan melibatkan siswa secara langsung dalam proses pembelajaran (Samsurizal \&Suleman, 2016). Berdasarkan hal ini maka pemanfaatan tanaman hias di lingkungan sekolah sebagai media pembelajaran biologi dirasa perlu untuk dilaksanakan dalam proses pembelajaran (Angela \& Aprianto, 2018).

\section{METODE}

Penelitian ini dilaksanakan di pekarangan sekolah SMP Negeri 11 Sungai Penuh selama selama dua bulan. Penelitian ini dilaksanakan dalam dua tahapan yang meliputi tahap pertama 
yaitu menggunakan jenis penelitian deskriptif kualitatif bertujuan untuk menginterpretasi data yang akurat dan sistematik mengenai populasi tanaman hias yang ada di pekarangan sekolah SMP Negeri 11 Sungai Penuh. Metode yang digunakan adalah metode survey dengan Teknik jelajah, dengan cara mengitari lingkungan sekolah SMP Negeri 11 Sungai Penuh untuk mengidentifikasi jenis tanaman hias yang ada di pekarangan sekolah. Tanaman hias yang ditemukan diidentfikasi dan digunakan sebagai media pembelejaran biologi.

Populasi penelitian ini adalah semua jenis tumbuhan yang terdapat di pekarangan sekolah SMP Negeri 11 Kerinci. Sampel penelitian ini yaitu semua jenis tanaman hias yang terdapat di pekarangan sekolah SMP Ngeri 11 Sungai Penuh. Adapun Teknik Analisa data yaitu dibagi menjadi dua tahapan. Teknik Analisa data tahap pertama yaitu Analisa secara deskriptif jenis-jenis tanaman hias menggunakan gambar, referensi dari internet dan menggunakan buku kunci determinasi. Jenis tanaman hias yang ditemukan di pekarangan sekolah dibuat deskripsi morfologinya dan diklasifikasi sesuai kedudukan dalam berdasarkan ilmu taksonomi. Hasil identifikasi dibuat dalam bentuk album foto untuk dimanfaatkan sebagai media pembelajaran biologi. Tahapan kedua dalam penelitian ini yaitu merupakan penelitian deskriptif kuantitatif. Pengumpulan data pada tahapan kedua yaitu Analisa kuantitatif berupa data angket respon siswa dalam menggunakan media pembelajaran hasil identifikasi tanaman hias. Populasi penelitian tahap kedua yaitu siswa Kelas VIII SMP Negeri 11 Sungai Penuh dan sampel penelitian yaitu siswa kelas VIII A dan B. Sampel ditentukan dengan menggunakan Teknik total sampling. Instrument penelitian tahap kedua ini yaitu angket respon siswa menggunakan media pemebelajaran tanaman hias dalam pembelajaran biologi. Data hasil angekt dioleh dengan menggunakan rumus:

$$
\mathrm{P}=\frac{\sum \text { Skor per item }}{\text { Skor maks per item }} \times 100 \%
$$

Tabel 1. Kategori Hasil Penilaian Observer

\begin{tabular}{cc}
\hline Interval (\%) & Kategori \\
\hline $0-20$ & Tidak baik \\
\hline $21-40$ & Kurang baik \\
\hline $41-60$ & Cukup \\
\hline $61-80$ & Baik \\
\hline $81-100$ & Sangat baik \\
\hline
\end{tabular}

(Riduwan, 2009) 


\section{HASIL DAN PEMBAHASAN}

\section{Jenis Tanaman Hias di Pekarangan Sekolah SMP Negeri 11 Sungai Penuh}

Berdasarkan hasil penelitian danidentifikasi jenis tanaman hias yang terdapat di pekarangan sekolah SMP Negeri 11 Sungai Penuh diperoleh data pada tabel 1.

Tabel 2. Jenis Tanaman Hias di Pekarangan Sekolah SMP Negeri 11 Sungai Penuh

\begin{tabular}{|c|c|c|c|}
\hline No & Familia & Species & Nama Lokal \\
\hline 1 & Nyctaginaceae & Bougenvillea sp & Bunga Kertas \\
\hline 2 & Myctaceae & Syzigium oleana & Pucuk Merah \\
\hline 3 & Apocynaceae & Adenium obesum & Bunga Kamboja \\
\hline 4 & Verbenaceae & Lantana camara & Bunga Tahi Ayam \\
\hline 5 & Rubiaceae & Ixora coccinea & Bunga asoka \\
\hline 6 & Malvaceae & Hibiscus rosa sinensis & Bunga Kembang Sepatu \\
\hline 7 & Apocynaceae & Allmanda cathartica $L$. & Bunga Alamanda \\
\hline 8 & Pteridaceae & Adiantum sp & Suplir \\
\hline 9 & & Aglonema sp & Keladi \\
\hline 10 & & Dieffenbachia sp & Daun Bahagia \\
\hline 11 & $\Delta$ rosor & Caladium sp. & Keladi Tengkorak \\
\hline 12 & Araceae & Anthurium schott & Gelombang Cinta \\
\hline 13 & & Dahlia pinnata & Bunga Dahlia \\
\hline 14 & & Helianths annus & Bunga Matahari \\
\hline 15 & & Callitephus sp. & Bunga Aster \\
\hline 16 & Asparagaceae & Sansevieria cylindrica & Lidah Mertua \\
\hline 17 & & Aloe vera $L$. & Lidah Buaya \\
\hline 18 & Amaranthaceae & Celosia cristata & Bunga Jengger Ayam \\
\hline 19 & Agavaceae & Polianthes tuberosa & Bunga Sedap Malam \\
\hline
\end{tabular}

Berdasarkan tabel 1. Diperoleh hasil identifikasi spesies tanaman hias yang berada di pekarangan sekolah SMP Negeri 11 Sungai Penuh yaitu sebanyak 19 spesies yang terdiri dari familia Nyctaginaceae, Myctaceae, Apocynaceae, Verbenaceae, Rubiaceae, Malvaceae, Apocynaceae, Pteridaceae, Araceae, Asparagaceae, Amaranthaceae, Agavaceae. Spesies yang paling banyak ditemukan yaitu familia Araceae sebanyak 7 spesies. Tanaman hias yang ditemukan di pekarangan sekolah SMP Negeri 11 Sungai Penuh merupakan jenis tanaman hias yang dibudidayakan. Berdasarkan hasil identifikasi diperoleh bahwa tanaman hias yang ada di pekarangan sekolah SMP Negeri 11 Sungai Penuh termasuk dalam kelompok tanaman hias bunga dan tanaman hias daun. Tanaman hias bunga merupakan jenis tanaman hias yang dibudidayakan untuk mendapatkan manfaat keindahan dari bunganya sedangkan tanaman hias daun merupakan tanaman yang dibudidayakan 
karena daunnya memiliki nilai keindahan dan memberi kesan asri pada lingkungan( Zulkarnain: 2014)

\section{Hasil Penelitian Respon Siswa terhadap Media Tanaman Hias dalam Pembelajaran Biologi}

Hasil penelitian tahap kedua yaitu tentang respon siswa terhadap media pembelajaran tanaman hias. Hasil respon siswa pada tabel 2.

Tabel 3. Respon Siswa Terhadap Media Pembelajaran Tanaman Hias

\begin{tabular}{llll}
\hline No & \multicolumn{1}{c}{ Indikator } & \multicolumn{1}{c}{ Persentase } & \multicolumn{1}{c}{ Kriteria } \\
\hline 1 & Relevansi & $85,5 \%$ & Sangat Positif \\
\hline 2 & Perhatian & $94,2 \%$ & Sangat Positif \\
\hline 3 & Kepuasan & $90 \%$ & Sangat Positif \\
\hline 4 & Kepercayaan Diri & $87,5 \%$ & Sangat Positif \\
\hline & Rata-Rata & $89,3 \%$ & Sangat Positif \\
\hline
\end{tabular}

Tabel 2. Menjelaskan persentase respon siswa terhadap media pembelajaran tanaman hias yang digunakan dalam pembelajaran biologi pada materi keanaekaragaman tumbuhan. Persentase rata-rata respon siswa yaitu 89,3\% dengan kategori sangat baik. Menurut (Kusuma, Candramila dan Ariyati: 2017) respon siswa merupakan salah satu bentuk tanggapan terhadap perasaaan siswa yang mengikuti proses pembelajaran. Respon siswa dalam penelitiian ini diperoleh dengan menggunakan angket yang diisi oleh siswa setelah mengikuti proses pembelajaran dengan menggunakan media pembelajaran tanaman hias dalam bentuk album foto pada materi keanaekaragaman tumbuhan.

Pengukuran respon siswa pada peelitian ini menggunakan empat indikator yang meliputi relevansi, perhatian, kepuasan dan kepercayaan diri. Respon siswa terhadap relevansi media pembelajaran tanaman hias yang ada di pekarangan sekolah yaitu sebesar 85,5\% dengan kategori sangat baik. Hal ini menunjukkan bahwa media tanaman hias yang digunakan relevan dengan materi pembelajaran dan membantu siswa untuk memperoleh informasi secra konstektual. Pemanfaatan media pembelajaran yang dapat digunkan dalam kehidupan sehari-hari membantu siswa dalam memahami materi pembelajaran dan dalam proses pembelajaran (Abidin, 2006; Ferry, 2019).

Respon siswa pada indikator perhatian sebesar 94,2\% dengan kategori sangat baik. Hal ini menjelaskan bahwa penggunaan media dalam pembelajaran dapat menghasilkan pembelajaran yang menarik. Pada proses pembelajaran siswa diajaka untuk menikmati pembelajaran dengan mengamati secara langsung media pembelajaran tanaman hias hasil identifikasi dari jenis tanaman hias yang ada di pekarangan sekolah, sehingga siswa merasakan proses pembelajaran. Menurut (Kusuma, Candramila dan Ariyati: 2017) perhatian merupakan bentuk pengarahan energi dalam menghadapi suatu objek.

Kepuasaan merupakan rasa senang dalam mengikuti proses pembelajaran. Perasaaan senang ini diperoleh jika siswa mendapatkan penghargaan terhadap dirinya. Nilai persentase keupasaan siswa terhadap media pemeblajaran tanaman hias yaitu 90\% dengan kategori sangat baik. Hal ini menjelasakan bahwa pembelajaran dengan menggunakan media pembelajaran yang konstektual 
berupa tanaman hias yang ada di pekarangan sekolah menumbuhkan perasaan yang positif dan ketertarikan dari siswa untuk mengikuti proses pembelajaran karena siswa memperoleh pengalaman selama proses pembelajaran berlangsung. Pranita, Mahal, dan Sari (2017) menyatakan bahwa penggunaan media pembelajaran yang memanfaatkan alam sekitar memudahkan mahasiswa dalam mengidentifikasi jenis tanaman dan memberi pengalaman belajar kepada mahasiswa karena mahassiswa terlibat aktif dalam pembelajaran sehinga memberi kepuasaan bagi mahasiswa dalam mengikuti pembelajaran.

Persentase kepercayaan diri siswa terhadap penggunaan media pembelajaran tanaman hias dalam bentuk album foto yaitu $87,5 \%$ dengan kategori sangat baik. Hal ini menunjukkan bahwa pembelajaran dengan menggunakan media membuat siswa mempunyai rasa percaya diri. Rasa percaya diri ini tumbuh dari kemampuan siswa dalam menyelesaikan masalah dalam proses pembelajaran (Bandura: 1994). Pada materi keanekaragaman dengan menggunakan media pemeblajarana berupa album foto tanaman hias mengajak siswa untuk beripkir secara konstektual, siswa diajak untuk mengamati jenis-jenis tanaman hias dan memahami kedudukan jenis-jenis tanaman hias dalam taksonomi tumbuhan. Kepercayaan diri merupakan suatu keyakinan yang kuat pada diri sendiri untuk melakukan suatu tindakan yang bias dikontrol oleh diri sendiri. Menurut (Hendriana: 2017) kepercayaan diri mampu memperkuat motivasi untuk memperoleh keberhasilan dalam proses pembelajaran, akrena semakin tinggi kepercayaan diri terhadap kemampuan diri sendiri. Maka semakin kuat motivasi dan semangat untuk menyelesaikan permasalahan dan Pekerjaan. Pembelajaran konstektual dalam bentuk permainan dapat membangun kepercayaan diri siswa untuk memahami materi pembelajaran (Suhardita: 2011).

\section{KESIMPULAN}

Hasil penelitian tahap pertama yaitu spesies tanaman hias yag ditemukan di pekarangan SMP Negeri 11 Sungai Penuh sebanyak 19 spesies tanaman hias yang terdiri dari kelompok tanaman hias bunga dan kelompok tanaman hias daun. Spesies tanaman hias bunga sebanyak 12 spesies dan kelompok tanaman his daun sebanyak 7 spesies. Hasil penelitian tahap kedua yaitu respon siswa terhadap media pembelajaran tanaman hias yaitu dengan kategori baik dengan persentase $85 \%$.

\section{UCAPAN TERIMA KASIH}

Ucapan terimakasih penulis ucapkan kepada berbagai pihak yang telah membantu dalam penyelesaian penelitian ini baik berupa moril maupun materil. Penulis menyadari banyak kendala dan tantangan dalam menyelesaikan penelitian ini. 


\section{DAFTAR RUJUKAN}

Abidin, Z. (2006). Motivasi dalam Strategi Pembelajaran dengan Pendekatan 'ARCS'. Suhuf. 18 (2): $147-153$

Angela, L., \& Aprianto, R. (2018). Pengembangan Modul Biologi Berbasis Contextual Teaching and Learning (CTL) pada Materi Keanekaragaman Hayati Kelas X Madrasah Aliyah. Jurnal Edukasi Matematika dan Sains, 6(2), 93-102.

Bandura, A. (1994). Self-Efficacy. Dalam V. S. Ramachaudran (Ed.), Encyclopedia of Human Behavior, Vol. 4. New York: Academic Press. [Online]. Tersedia: http://www.des.emory.edu/mfp/BanE ncy.html

Ferry, D. (2019). Peningkatan Hasil Belajar dan Keaktifan Mahasiswa Melalui Strategi Pembelajaran Peta Konsep Pada Mata Kuliah Evolusi. Journal on Education, 1(4), 809816. Retrieved from http://www.jonedu.org/index.php/joe/article/view/249

Hariani, N. M. M. Jenis-Jenis Tumbuhan Di Sekitar Sekolah Sma Gkst Palu Dan Pengembangannya Sebagai Media Pembelajaran. JSTT, 5(3).

Hendriana, H. (2014). Membangun kepercayaan diri siswa melalui pembelajaran matematika humanis. Jurnal Pengajaran MIPA, 19(1), 52-60.

Kusuma, A. M., \& Candramila, W. Respon Siswa terhadap Pembelajaran Berbasis Masalah pada Materi Pencemaran Lingkungan di Kelas X SMA. Jurnal Pendidikan dan Pembelajaran, 6(10).

Pranita, H. S., Mahanal, S., \& Sari, M. S. (2016). Inventarisasi Tumbuhan Paku Kelas Filicinae di Kawasan Watu Ondo sebagai Media Belajar Mahasiswa.

Suhardita, K. (2011). Efektivitas penggunaan teknik permainan dalam bimbingan kelompok untuk meningkatkan percaya diri siswa. Jurnal UPI, Edisi Khusus, 10, 127-138.

Tjitrosoepomo, G. (1998). Dasar-Dasar Taksonomi Tumbuhan. Yogyakarta: UGM Press

Wulandari, D. Y., Saptasari, M., \& Mahanal, S. (2016). Pemanfaatan Tumbuhan Suku Poaeceae di Taman Hutan Raya R Soerjo sebagai Media Penunjang Identifikasi.

Zulkarnain, Z. (2009). Dasar-dasar hortikultura. Jakarta: PT Bumi Aksara. 